Praxis : Jurnal Sains, Teknologi, Masyarakat dan Jejaring | Vol. 3 | No. 2 | Maret 2021

\title{
Kajian Keindahan Lingkungan Taman Kota di Semarang Studi Kasus: Taman Pandanaran, Taman Tirto Agung, Taman Banjir Kanal Barat, Taman Sri Gunting, dan Taman Indonesia Kaya
}

\author{
Ratih Dian Saraswati'; Supriyono ${ }^{2}$ \\ Program Studi Arsitektur Fakultas Arsitektur dan Desain \\ Universitas Katolik Soegijapranata Semarang \\ email: ${ }^{1}$ rd_saraswati@unika.ac.id; ${ }^{2}$ supriyono@unika.ac.id
}

\begin{abstract}
City park is one type of public open space, which is located in a strategic place in the city area. Its main function is as a facility for people to gather, moreover as the lungs of the city. City parks in the city of Semarang are scattered throughout the city of Semarang, in the form of active and passive city parks. Active city parks, are places where people gather for activities, interact, and socialize. This research on five city parks in the city of Semarang aims to determine the beauty elements of each city park. This environmental aesthetic study is based on Berlyne's theory with a qualitative descriptive method. The results are comparisons of urban park's observation of complexity, uniqueness, absence, and surprise.
\end{abstract}

Keywords: city park, public open space, environmental aesthetics

\begin{abstract}
Abstrak
Taman kota merupakan salah satu jenis ruang terbuka publik, yang terletak pada tempat yang strategis diwilayah kota. Fungsi utamanya adalah sebagai fasilitas bagi masyarakat untuk berkumpul, disamping fungsi lainnya, yaitu sebagai paru paru kota. Taman kota yang ada di kota Semarang, tersebar di wilayah kota Semarang, berupa taman kota bersifat aktif maupun pasif. Taman kota aktif, merupakan tempat berkumpulnya masyarakat untuk beraktifitas, berinteraksi dan bersosialisasi. Penelitian terhadap lima taman kota di kota Semarang ini bertujuan untuk mengetahui unsur keindahan dari masing-masing taman kota. Kajian estetika lingkungan ini berdasarkan teori Berlyne dengan metode deskriptif kualitatif. Hasil penelitian berupa perbandingan pengamatan taman kota berdasarkan faktor kompleksitas, keunikan, ketidaksenadaan, dan kejutan.
\end{abstract}

Kata kunci: taman kota, ruang terbuka publik, keindahan lingkungan

\section{PENDAHULUAN}

Taman kota merupakan fasilitas ruang publik yang disediakan pemerintah sebagai salah satu bentuk pelayanannya, baik yang berupa taman kota aktif maupun pasif. Pada taman kota aktif, masyarakat kota dapat beraktifitas, berinteraksi dan bersosialisasi antara satu dengan lainnya. Sedangkan taman kota pasif berfungsi sebagai paru paru kota, untuk kenyamanan visual dan keindahan kota.

Pasal 29 Undang Undang RI No 26 tahun 2007 tentang tata ruang, mensyaratkan bahwa suatu kota harus mempunyai minimal $30 \%$ ruang terbuka hijau yang terdiri dari $20 \%$ terbuka hijau publik dan sisanya ruang terbuka hijau privat. Hal ini ditunjang oleh Peraturan Menteri PU No: 
05/PRT/M/2008 tentang Pedoman Penyediaan dan Pemanfaatan Ruang Terbuka Hijau di Kawasan Perkotaan. Ruang terbuka public dapat berupa sebuah lapangan, hutan kota, trotoar, atau taman kota. Taman kota ada yang bersifat pasif, artinta hanya sebagai taman yang bernilai estetika saja, namun ada taman aktif yang dapat dijadikan sarana kegiatan masyarakat kota.

Kota Semarang pada akhir akhir ini sedang menggalakkan keberadaan taman kota baik aktif maupun pasif, dengan pengadaan baru maupun merenovasi taman kota yang sudah ada. Hal itu disamping untuk memenuhi amanat Undang Undang RI No 26, juga sebagai bentuk pelayanan pemerintah kota (Pemkot) kepada masyarakatnya. Di kota Semarang ada beberapa taman aktif, yang akan dijadikan obyek penelitian ini, antara lain: Taman Pandanaran, Taman Tirto Agung, Taman Banjirkanal Barat, Taman Srigunting, dan Taman Indonesia Kaya.

Pada penelitian ini akan mengambil seting ke lima taman kota tersebut. Penelitian akan berfokus pada keindagan lingkungan pada setiap seting taman kota.

\section{KEASLIAN PENULISAN}

Penelitian dengan topik taman kota telah banyak dilakukan oleh sejumlah peneliti karena topik tersebut menarik untuk diteliti dan isunya faktual. Beberapa penelitian mengenai taman kota di kota Semarang juga sudah dilakukan. Namun penelitian yang banyak dilakukan adalah mengkaji dari aspek fungsi taman, bukan mengkaji keindahan lingkungan taman kota. Penelitian yang pernah dilakukan sebelumnya dengan judul Estetika Lingkungan Bantaran Sungai Banjirkanal Barat Semarang (Supriyono dan Nestri, 2017) dengan temuan hasil adalah keindahan lingkungan yang melihat dari pendapat pengunjung dan pengamatan peneliti. Sedangkan penelitian yang ini dengan judul Kajian Keindahan Lingkungan Taman Kota di Kota Semarang menghasilkan perbandingkan lima taman kota yang memiliki seting lokasi strategis di tengah kota Semarang berdasarkan faktor-faktor keindahan lingkungan.

\section{LANDASAN TEORI}

Taman kota sebagai ruang terbuka publik sangat dibutuhkan oleh masyarakat kota, sebagai ruang beraktivitas, berinteraksi dan bersosialisasi, melepas kepenatan serta bermain dengan sesama warga kota. Hal ini dilakukan setelah seharian disibukkan oleh kegiatan yang padat, rutinitas harian yang sama, sehingga membosankan dan tempat atau area yang 12 sebagian besar berada didalam ruang tertutup yang dirasakan sangat membelenggunya (Manurung, 2018). Ruang terbuka publik dapat berupa lapangan, taman kota (baik taman aktif maupun pasif), hutan kota atau trotoar sebagai ruang untuk pejalan kaki atau juga bisa untuk beraktivitas warga kota.

Penilaian terhadap keindahan lingkungan bergantung pada intrepretasi individu, keindahan/estetika dipengaruhi oleh kesukaan (preferensi) yang ditentukan oleh aspek; keteraturan tekstur, keakraban dengan lingkungan, keleluasan pandang, kemajemukan rangsang, misteri dan kerahasiaan yang tersembunyi dari pandangan (S Kaplan, 1995) artinya pada lingkungan yang sama, penilaian antara orang yang satu dengan lainnya dapat tidak sama. Menurut Berlyne (dalam Sarwono, 1992), faktor - faktor yang berkaitan dengan keindahan lingkungan adalah:

1. Kompleksitas, yaitu berapa banyak ragam komponen yang membentuk suatu lingkungan. Makin banyak 
ragamnya, makin positif penilaian yang diberikan.

2. Keunikan dan novelty, yaitu seberapa jauh lingkungan itu mengandung komponen-komponen yang unik, yang tidak ada di tempat lain, atau hal-hal baru yang sebelumnya tidak pernah dilihat.

3. Ketidak senadaan atau incongruity, sampai seberapa jauh salah satu atau beberapa komponen yang ada dilingkungan tersebut tidak cocok dengan konteks lingkungannya.

4. Kejutan, yaitu seberapa jauh kenyataan yang tidak sesuai dengan harapan.

\section{METODE PENELITIAN}

Metode penelitian ini awalnya direncanakan dengan melakukan pengamatan langsung dan wawancara, akan tetapi terkendala dengan adanya pandemic covid-19. Pengambilan data dilakukan secara sekunder, dari media daring. Data yang telah didapat selanjutnya dianalisa berdasarkan faktor-faktor yang berkaitan dengan estetika secara kualitatif lalu hasil penelitaian ditulis secara kualitatif deskriptif.

\section{HASIL PENELITIAN DAN PEMBAHASAN}

\section{A. Taman Pandanaran}

Taman Pandanaran berlokasi di kota Semarang bawah, di salah satu sisi Jalan Pandanaran, tepatnya di pertigaan Jalan Pandanaran dan Jalan Thamrin (di depan Universitas Unisbank), sekitar 200 meter dari Simpang Lima Semarang. Taman ini dulunya adalah komplek SPBU, yang sekarang didesain sebagai taman kota.

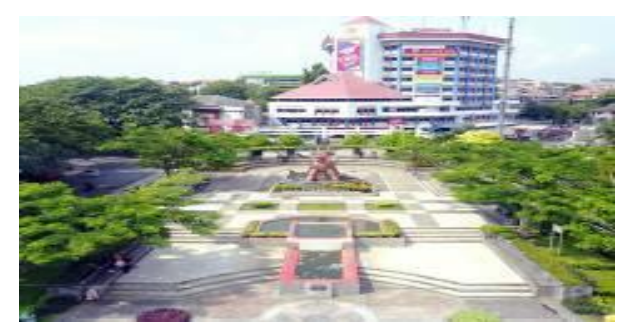

Gambar 1

Taman Pandanaran yang berada di muka depan sebuah universitas swasta di Semarang Sumber:

https://www.tempatwisata.pro/wisata/Semarang

Taman ini sebagai sebuah taman kota yang bersifat taman aktif, selain bermacam vegetasi pepohanan dan berbunga, taman Pandanaran memiliki fasilitas antara lain:

1. Patung Warak Ngendog yang berukuran monumental, merupakan patung berbentuk binatang imajiner yang menjadi ikon kota Semarang. Patung ini merupakan simbol tiga etnis terbesar warga kota Semarang, yaitu: Jawa, China, dan Arab. Kata "warak" berasal dari bahasa Arab yang bermakna 'suci'. (https://semarangcityheritage.wordpre ss.com/warag-ngendog

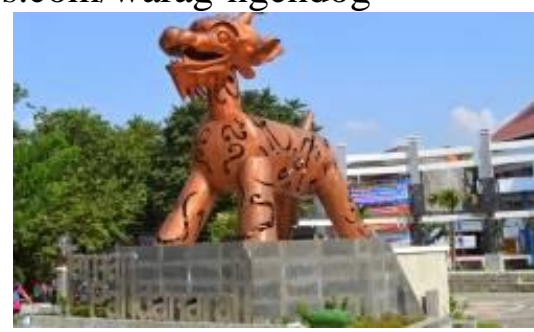

Gambar 2

Patung Warak Ngendhog sebagai ikon taman Pandanaran

Sumber: https://energibangsa.id/mengapawarak-ngendog-jadi-icon-kota-semarang/

2. Ampiteater, sebagai ruang luas di tengah taman, digunakan pengunjung untuk duduk santai, bersantai dan aktifitas lainnya. Keberadaan ampiteater pada taman Pandanaran sebetulnya kurang tepat karena lingkungan di sekitar taman berupa jalan utama, sehingga kebisingan tinggi. Selain itu, dengan tidak adanya 
Praxis : Jurnal Sains, Teknologi, Masyarakat dan Jejaring | Vol. 3 | No. 2 | Maret 2021

jadwal pertujukkan, maka ampiteater sering kosong.

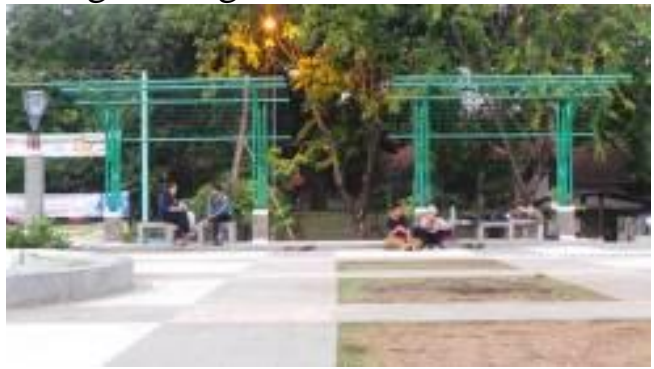

Gambar 3

Ampiteater di tengah taman Pandanaran Sumber:

https://m.tribunnews.com/travel/2015/08/04/ta man-pandanaran-ruang-publik-di-pusatsemarang-dilengkapi-wifi-24-jam

3. Sitting group dengan kanopi, fasilitas untuk duduk-duduk santai pengunjung bersama teman, keluarga, dan sebagainya. Area duduk ini dimanfaatkan oleh pengunjung untuk duduk, bersantai, bercengkrama dan sebagainya. Pada masa sebelum pandemik, selain warga yang tinggal di lingkungan taman, mahasiswa Unisbank dan siswa SMA Nasima yang kampusnya berada di dekat taman juga memanfaatkan.

4. Kran minum, fasilitas berupa kran air yang air minumnya bisa langsung diminum. Kran air minum ini tidak bertahan lama karena ada beberapa pengunjung yang tidak bisa menjaga atau ikut merawat, sehingga kran sering rusak atau patah.

5. Parkir sepeda, fasilitas ini bagi pengunjung yang kebanyakan adalah pengendara komunitas sepeda yang mampir dan bersitirahat di taman.

6. Pedestrian dan ramp, jalur pedestrian mengelilingi area taman dilengkapi dengan jalur untuk tuna netra dan ramp untuk akses masuk ke taman.

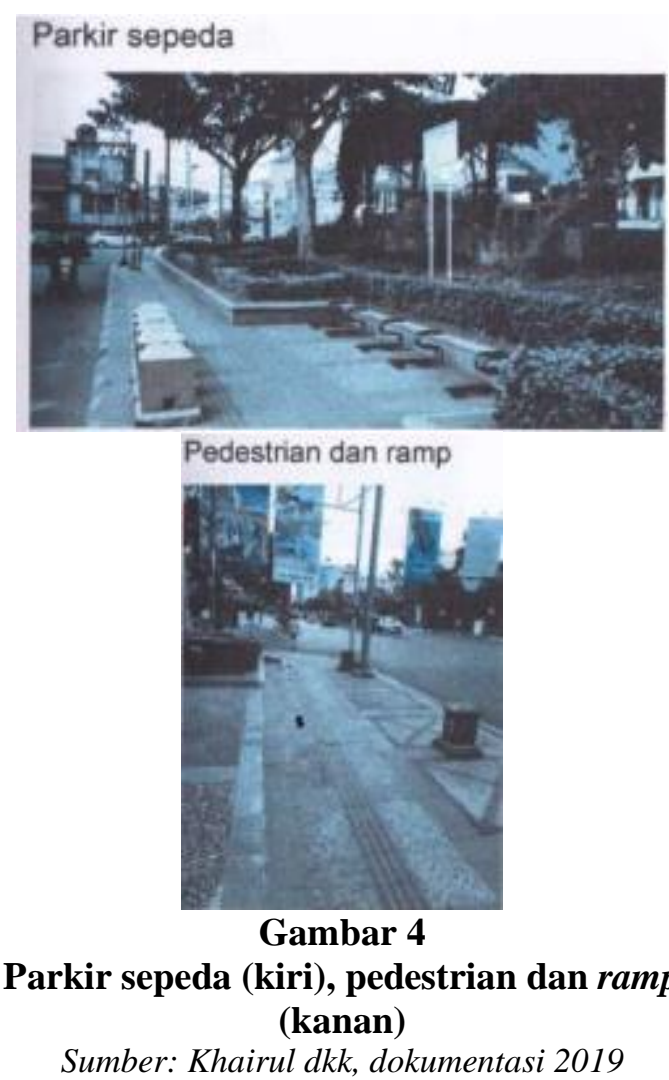

7. Kolam air mancur, merupakan elemen estetis yang ada di tengah taman, memebrikan suasana sejuk terutama pada siang hari. Tempat ini menjadi salah satu spot selfie pengunjung.

\section{B. Taman Tirto Agung}

Taman Tirto Agung yang dibangun oleh pemerintah kota Semarang pada tahun 2011, terletak di Semarang atas, tepatnya di Jalan Tirto Agung, Banyumanik, dekat dengan lingkungan perumahan. Taman ini memiliki seting yang luas dengan fasilitas lengkap dan mewadahi beberapa aktifitas, antara lain:

1. Berdagang, terdapat banyak pedagang yang menjajakan dagangannya, baik yang menetap maupun yang berkelililing. Dagangan yang dijajakan berupa mainan anak, makanan, dan minuman. Pedagang yang menetap memakai tenda dan gerobak di sekeliling area taman.

2. Penyedia jasa mainan anak-anak (area playground), persewaan mainan anak-anak ada di dalam taman berupa mobil-mobilan, 
kereta, sepeda dan sebagainya. Ada juga wahana permainan untuk anak-anak.

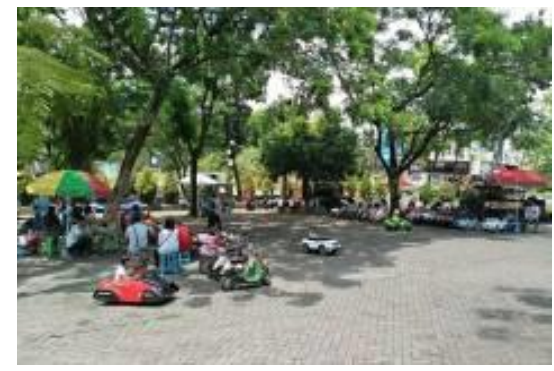

Gambar 5

Salah satu spot taman untuk berdagang dan persewaan mainan anak-anak (foto sebelum pandemi) Sumber:

http://www.kontenpedia.com/detail/news/4 82094/gaya\%20hidup/taman-tirto-agungbanyumanik-alternatif-refresing-keluarga-

3. Olah-raga, area olah-raga yang spesifik adalah wall climbing, selain itu juga ada lapangan bola voli. Pengunjung bisa juga jogging dan senam di dalam area taman. Dengan adanya sarana olah-raga ini, maka taman Tirto Agung memiliki cir khas tersendiri, dibanging taman-taman kota lain di kota Semarang.

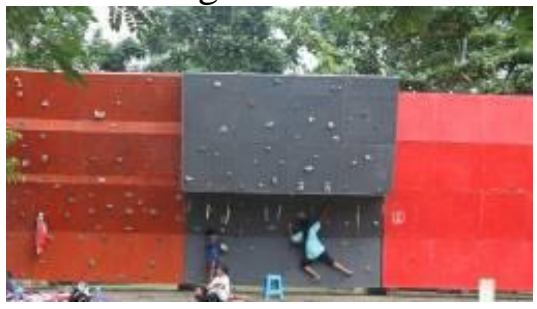

Gambar 6

Wall climbing yang ada pada taman Tirto Agung

Sumber:

https://jateng.tribunnews.com/2017/01/25/ bersantai-sambil-kulineran-atauberolahraga-taman-tirto-agungsemarang-bisa-jadi-jujugan

4. Bercengkrama, pengunjung banyak yang datang hanya untuk mengobrol, bersantai bersama teman dan keluarga. Taman ini menyediakan sitting group yang teduh ternaungi pepohonan dan juga ada fasilitas wifi. Selain itu, banyak pengunjung yang datang dari komunitas pecinta burung.

\section{Taman Banjir Kanal Barat}

Taman Banjir Kanal Barat terletak di Jalan Simongan, tepatnya di bantaran sungai Banjir Kanal Barat, dekat dengan bendungan Pleret.

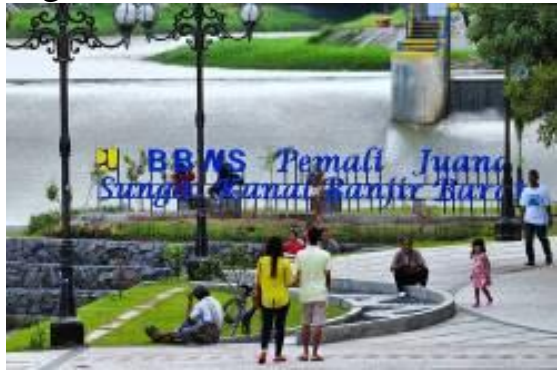

Gambar 7

Bendungan Pleret, karena sering dipakai mainan anak-anak untuk pleretan (berseluncur)

Sumber:

https://pemkotsemarang2016.wordpress.com/2017/ 03/05/bendungan-sungai-banjir-kanal-barat/

Pada awalnya sungai Banjir Kanal Barat kotro, penuh dengan sampah, dan bantarannya tidak terawat, di mana pada musim kemarau terjadi pendangkalan dan pada musim hujan akan membawa banjir. Setelah dilakukan pengerukan dasar sungai, membangun ruang-ruang terbuka untuk rekreasi dan aktifitas publik di kanan-kiri bantaran, maka sungai tersebut menjadi semakin bersih, indah, tertata dengan baik, dan menjadi salah satu tempat rekreasi baru di kota Semarang. Fasilitas pendukung taman kota yang ada, antara lain:

1. Sitting group dengan kanopi tanaman, keadaan tempat duduk baik dan cukup rindang dengan provasi yang cukup terjaga.

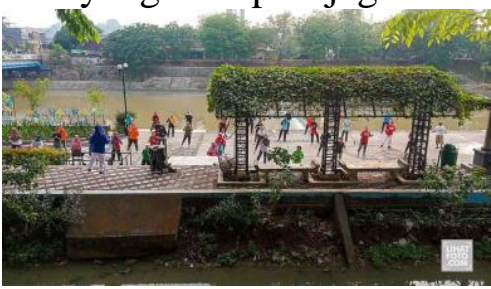

Gambar 8

Pengunjung melakukan senam bersama di depan area sitting group yang ada pada lokasi seting

Sumber: https://lihatfoto.com/senam-ditaman-bantaran-sungai-bkb-semarang17030 
Praxis : Jurnal Sains, Teknologi, Masyarakat dan Jejaring | Vol. 3 | No. 2 | Maret 2021

2. Jogging track dengan area batu pijat sebagai pelengkapnya, merupakan salah satu fasilitas yang ada di dalam taman, walaupun tidak panjang. Apabila masih ingin lebih jauh lagi, ada jogging track lain yang berada di sepanjang bantaran Sungai Banjirkanal Barat, memanjang dari Banjir Kanal Lemah Gempal sampai jembatan Jalan Jendral Sudirman. Area batu pijat sering digunakan pengunjung yang sudah lanjut usia, untuk melemaskan syaraf-syaraf kaki.

3. Area memancing di bantaran sungai, banyak dimanfaatkan oleh pengunjung yang hobi memancing. Fasilitas ini menjadi kekhasan sendiri untuk taman kota ini. Sayangnya fasilitas ini belum ditata dengan baik, kondisinya berkesan kotor termasuk adanya sampahsampah di sungai.

\section{Taman Srigunting}

Taman Srigunting ini terletak di Jalan Letjen Suprapto, sebelah Gereja Blenduk, Kota Lama Semarang. Keberadaan taman tematik ini menyatu dengan bangunan cagar budaya di sekitarnya. Taman ini pada masa colonial Belanda berwujud parade pelin untuk panggung parade, atau tempat Belanda berkegiatan militer, namun saat ini merupakan ruang terbuka publik, yang memiliki fasilitas antara lain:

1. Beberapa spot untuk foto selfie, dengan latar belakang Gereja Blenduk dan bangunan kolonial lainnya. Dengan banyaknya pengunjung yang berfoto, disesidakan aksesoris taman, seperti: sepeda, becak kuno, topi, dan sebagainya.

2. Sitting group, beberapa titik tempat duduk yang diatur secara tidak formal, atau pengunjung hanya duduk pada kanstin pembatas saja dengan santai. Keberadaan pohon yang rindang dan tanaman perdu sangat membantu menurunkan suhu pada taman, mengingat lokasinya yang dekat dengan laut. Asesoris yang ada pada taman akan memperkuat karakter dari taman tersebut.

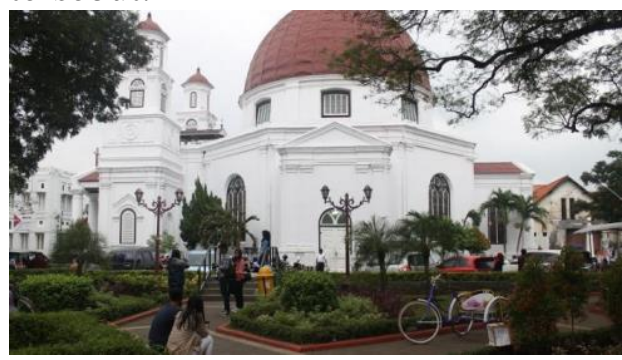

Gambar 8

Taman Srigunting berlatar belakang bangunan Gereja Blenduk Sumber:

https://jateng.tribunnews.com/2017/11/01/ enam-spot-foto-paling-ngehit-di-tamansrigunting-semarang-nyesel-kalau-ngganarsis-di-sini

3. Pedestrian, yang ada pada taman Srigunting didesain untuk dijadikan sitting group, dimana pengunjung dapat melepaskan lelah di pedestrian ini, setelah berkeliling di kota lama. Pedestrian ini juga berfungsi untuk tempat berkumpulnya wisatawan setelah berkeliling dan menikmati suasana kota lama secara bebas, karena aksesnya mudah.

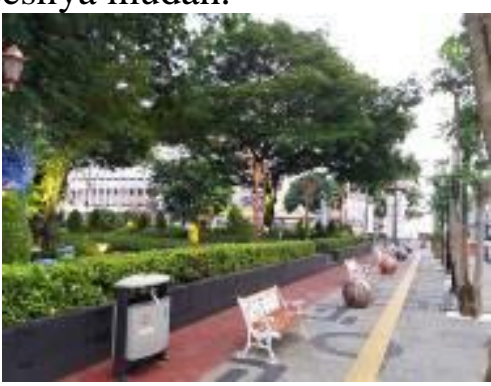

Gambar 9

Pedestrian di sisi depan Taman Sriguntin yang dilengkapi dengan bangku dan tempat sampah Sumber:

https://www.tripadvisor.com/LocationPhot oDirectLink-g297712-d10162130i304564631-Taman_SriguntingSemarang_Central_Java_Java.html

4. Keran air minum, disediakan fasilitas air bersih yang langsung dapat diminum. Hal ini sangat membantu pengunjung akan kebutuhan air minum, mengingat 
pada musim kemarau, kawasan kota lama hawanya sangat panas.

\section{E. Taman Indonesia Kaya}

Taman Indonesia Kaya adalah ruang terbuka publik yang berlokasi di jl Jl. Menteri Supeno Mugassari Semarang. Dulu taman ini dikenal dengan nama taman Menteri Supeno, atau juga yang sering dikenal dengan nama Taman KB, karena ada patung ibu dengan 2 anaknya sebagai lambang keluarga berencana (KB). Letak Taman Indonesia Kaya tidak jauh dari Simpang Lima Semarang, dan setelah di renovasi berganti nama menjadi Taman Indonesia Kaya. Taman dengan luas $5.000 \mathrm{~m} 2$ ini diresmikan pada tanggal 10 Oktober 2018. Sesuai namanya, Taman Indonesia Kaya memperlihatkan keragaman kebudayaan Nusantara. Taman Indonesia Kaya merupakan taman yang ramah difabel. Setiap jalan tersedia jalur khusus bagi pengguna kursi roda. Fasilitas yang tersedia, antara lain:

1. Panggung teater, merupakan fasilitas utama yang ada pada taman ini, dimana dilengkapi dengan ruang Atraksi budaya yang sudah menjadi agenda bulanan itu sengaja digelar untuk menghibur pengunjung bermalam mingguan di Taman Indonesia Kaya. Panggung Teater berkapasitas 1000 penonton yang duduk mengelilingi panggung.

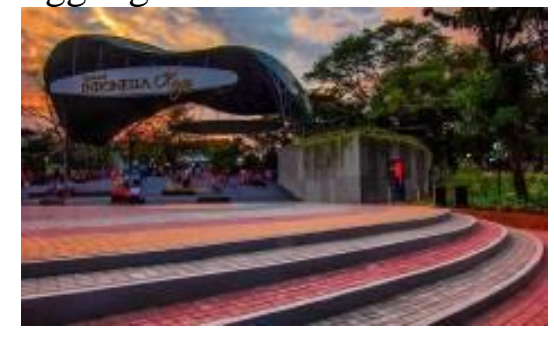

Gambar 10

Panggung pada Taman Indonesia Kaya dilengkapi dengan tempat duduk teater

Sumber: https://jejakpiknik.com/tamanindonesia-kayal

2. Sitting group, ada beberapa titik disediakan bangku. Selain itu, pengunjung juga dapat duduk dengan bebas didepan panggung teater apabila sedang tidak ada kegiatan atau pertunjukan.

3. Air mancur, merupakan area permainan. Tidak ada area permainan (playground) lain bagi anak-anak di area taman ini, sehingga apabila tidak senang dengan jenis permainan ini karena takut, sakit, tidak membawa ganti pakaian atau lainnya, tidak ada pilihan yang lain. Ada pula pertunjukan air mancur yang bisa disaksikan berkala.

4. Pedestrian, disediakan bagi penggemar olah-raga jalan santai atau bagi yang ingin meninkmati taman sambal berjalan berkeliling. Jalur pejalan kaki nyaman, dengan pohon rindang dan tanaman perdu yang terawat.

5. Keran air minum dan jaringan nirkabel.

6. Patung (sculpture), memperindah taman dan dipasang beberapa patung dengan tema kebebasan dan Pandawa Lima.Selain itu, ada mural yang sering dipakai oleh pengunjung untuk foto selfie.

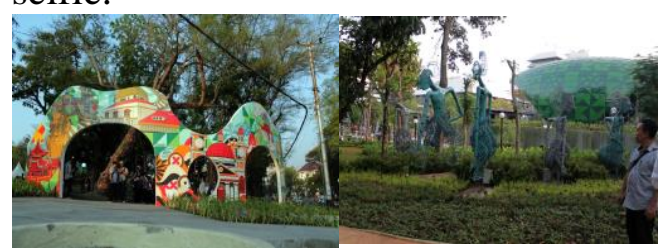

Gambar 11

Gerbang taman hasil karya lima seniman muda Semarang (kiri), patung Pandawa Lima (kanan)

Sumber: https://www.brilio.net/wow/7spot-kece-taman-indonesia-kaya-adagerbang-mural-yang-instagramable1810137.html\#

Berdasarkan uraian penelitian fasilitasfasilitas yang ada pada lima taman kota, maka dapat dibuat hasil perbandingan keindahan lingkungan yang meliputi: kompleksitas, keunikan, ketidaksenadaan, kejutan (tabel 1). 
Praxis : Jurnal Sains, Teknologi, Masyarakat dan Jejaring | Vol. 3 | No. 2 | Maret 2021

Tabel 1

Perbandingan Keindahan Lingkungan Taman Kota

\begin{tabular}{|c|c|c|c|c|}
\hline Taman & Kompleksitas & Keunikan & $\begin{array}{l}\text { Ketidak } \\
\text { senadaan }\end{array}$ & Kejutan \\
\hline Pandanaran & $\begin{array}{l}\text { Cukup indah dengan } \\
\text { berbagai macam ragam } \\
\text { komponen; hard } \\
\text { material dan soft } \\
\text { material. }\end{array}$ & $\begin{array}{l}\text { Keberadaan patung } \\
\text { Warak Ngendog } \\
\text { yang besar dan } \\
\text { dominan. }\end{array}$ & $\begin{array}{l}\text { Keberadaan } \\
\text { yang ada di } \\
\text { tengah kota, } \\
\text { berada di } \\
\text { lingkungan yang } \\
\text { berupa } \\
\text { bangunan } \\
\text { berlantai } \\
\text { banyak. }\end{array}$ & $\begin{array}{l}\text { Keberadaan } \\
\text { patung Warak } \\
\text { Ngendog yang } \\
\text { berukuran besar } \\
\text { menimbulkan } \\
\text { kejutan. }\end{array}$ \\
\hline Tirto Agung & $\begin{array}{l}\text { Taman ini indah karena } \\
\text { beragam komponen } \\
\text { pendukung, baik yang } \\
\text { bersifat rekreasi } \\
\text { maupun kesehatan. }\end{array}$ & $\begin{array}{l}\text { Keberadaan sarana } \\
\text { olahraga berupa } \\
\text { wall climbing yang } \\
\text { merupakan satu- } \\
\text { satunya taman di } \\
\text { kota Semarang } \\
\text { yang memiliki } \\
\text { fasilitas seperti itu. }\end{array}$ & $\begin{array}{l}\text { Beragam } \\
\text { fasilitas yang } \\
\text { dengan } \\
\text { bentuknya yang } \\
\text { beraneka ragam }\end{array}$ & $\begin{array}{l}\text { Fasilitas wall } \\
\text { climbing yang } \\
\text { tidak terlihat dari } \\
\text { jalan. }\end{array}$ \\
\hline $\begin{array}{l}\text { Banjir Kanal } \\
\text { Barat }\end{array}$ & $\begin{array}{l}\text { Taman ini indah karena } \\
\text { adanya komponen } \\
\text { buatan dan alami yang } \\
\text { berupa sungai. }\end{array}$ & $\begin{array}{l}\text { Taman yang } \\
\text { memiliki } \\
\text { keleluasaan } \\
\text { pandang karena } \\
\text { berada di tepi } \\
\text { sungai. }\end{array}$ & $\begin{array}{l}\text { Beragam } \\
\text { fasilitas dengan } \\
\text { bentuk yang } \\
\text { beraneka ragam } \\
\text { pula; komponen } \\
\text { buatan yang } \\
\text { kontras dengan } \\
\text { komponen } \\
\text { alami. }\end{array}$ & $\begin{array}{l}\text { Keberadaan } \\
\text { bendungan Pleret } \\
\text { merupakan kejutan } \\
\text { pada taman ini. }\end{array}$ \\
\hline Sri Gunting & $\begin{array}{l}\text { Taman ini juga indah } \\
\text { karena banyak } \\
\text { komponen yang } \\
\text { mendukung dan } \\
\text { terawat. }\end{array}$ & $\begin{array}{l}\text { Keadaan } \\
\text { lingkungan } \\
\text { sekeliling yang } \\
\text { didominasi oleh } \\
\text { bangunan kolonial }\end{array}$ & $\begin{array}{l}\text { Terlihat ada } \\
\text { kesenadaan } \\
\text { antara taman } \\
\text { dengan } \\
\text { lingkungannya. }\end{array}$ & $\begin{array}{l}\text { Tidak ada karena } \\
\text { ketika masuk } \\
\text { kawasan sudah } \\
\text { memberi kesan } \\
\text { kota lama dengan } \\
\text { cagar budayanya. }\end{array}$ \\
\hline Indonesia Kaya & $\begin{array}{l}\text { Taman ini berkesan } \\
\text { sangat indah karena } \\
\text { banyak ragam } \\
\text { komponen yang } \\
\text { mendukung. }\end{array}$ & $\begin{array}{l}\text { Bangunan teater } \\
\text { terbuka dengan } \\
\text { kapasitas sampai } \\
1000 \text { orang. }\end{array}$ & $\begin{array}{l}\text { Bangunan teater } \\
\text { terbuka yang } \\
\text { memiliki } \\
\text { karakter berbeda } \\
\text { dengan } \\
\text { lingkungan } \\
\text { sekitarnya. }\end{array}$ & $\begin{array}{l}\text { Keberadaan } \\
\text { bangunan teater } \\
\text { yang berskala } \\
\text { besar dapat } \\
\text { menimbulkan } \\
\text { kesan berbeda } \\
\text { terutama bagi } \\
\text { pengunjung yang } \\
\text { baru pertama kali } \\
\text { datang ke taman } \\
\text { ini. }\end{array}$ \\
\hline
\end{tabular}


Praxis : Jurnal Sains, Teknologi, Masyarakat dan Jejaring | Vol. 3 | No. 2 | Maret 2021

Berdasarkan tabel perbandingan kajian keindahan lingkungan pada ke lima taman kota tersebut dapat ditelaah, sebagai berikut:

1. Kompleksitas, ke lima taman kota tersbeut memiliki keberagaman komponen sebuah taman yang mendukung, baik hard material maupun soft material, maka ke lima taman tersebut mendapatkan penilaian yang positif dan indah.

2. Keunikan atau Novelty, setiap taman kota memiliki keunikan masing-masing sesuai seting lokasi di mana taman tersebut berada. Hal ini menjadikan masing-masing taman memiliki kekhasan dan memiliki ikon tersendiri.

3. Ketidaksenadaan atau incongruity, dari ke lima taman kota tersebut beberapa komponen yang bersifat buatan tidak senada dengan lingkungan seting di mana tersebut berada. Hal ini dikarenakan setiap taman kota berlomba untuk menyediakan fasilitas untuk berbagai fungsi kegiatan, yang kontras terhadap bangunan sekitar.

4. Kejutan, beberapa taman kota memiliki komponen taman yang memberikan kejutan bagi pengunjung yang baru pertama kali datang. Kejutan dari komponen tersebut beberapa berupa ikon yang monumental/ skala besar seperti pada Taman Pandanaran, Taman Tirto Agung, dan Taman Indonesia Kaya. Ada juga kejutan karena komponen alami seperti pada Taman Banjirkanal Barat.

\section{SIMPULAN}

Taman kota memiliki fungsi yang pentik sebagai salah satu ruang terbuka publik yang bisa dijangkau semua masyarakat, tanpa memandang latar belakang sosial, ekonomi dan agama. Melalui penelitian mengenai fasilitasfasilitas taman-taman kota di kota Semarang dapat disimpulkan bahwa setiap taman kota memiliki fasilitas yang dapat dimanfaatkan semua kalangan masyarakat, baik individu, kelompok maupun komunitas. Melihat dari aspek fungsi, taman-taman kota tersebut sudah cukup memenuhi harapan warga Semarang terhadap tempat rekreasi dan olah-raga namun masih kurang dalam hal penyediaan fasilitas untuk kaum difabel. Melihat aspek estetika lingkungan, taman-taman kota tersebut memiliki kelebihan dan kekurangan masing-masing. Penyediaan taman kota sebagai ruang terbuka publik harus diimbangi dengan faktor pengelolaan yang baik pula, akan lebih baik jika bisa menggandeng pihak ketiga (seperti contohnya Taman Indonesia Kaya). Pemerintah kota Semarang masih perlu menyediakan ruang terbuka publik berupa taman aktif yang estetis dan tematik di seluruh kecamatan yang ada, bisa dengan cara merenovasi taman yang ada maupun membuat taman baru. Perlu dipikirkan pula faktor perawatan dan pengawasan terhadap taman-taman tersebut karena masih ada sebagian pengguna yang kurang tanggap terhadap kebersihan, melakukan vandalisme dan pada malam hari, tidak digunakan oleh tunawisma, tempat untuk mabuk dan sebagainya.

\section{DAFTAR PUSTAKA}

Haryadi \& B Setiawan. (2010). Arsitektur, Lingkungan Dan Perilaku. Yogyakarta: Gadjah Mada University Press.

Halim, Deddy. (2005). Psikologi Arsitektur. Jakarta: Gramedia Widia Sarana.

Halim, DK. (2008). Psikologi Lingkungan Perkotaan. Jakarta: Bumi Aksara. 
Praxis : Jurnal Sains, Teknologi, Masyarakat dan Jejaring | Vol. 3 | No. 2 | Maret 2021

Laurens, Joyce Marcella. (2004). Arsitektur Dan Perilaku Manusia. Jakarta: Gramedia Widia Sarana dan Universitas Kristen Petra.

Manurung, Parmonangan. (2018). Kota Untuk Semua. Yogyakarta: Penerbit Andi.

Peraturan Menteri PU No: 05/PRT/M/2008 tentang Pedoman Penyediaan dan Pemanfaatan Ruang Terbuka Hijau di Kawasan Perkotaan

Supriyono \& MD Nestri Kiswari. (2017). Estetika Lingkungan Bantaran Sungai Banjirkanal Barat Semarang. Bogor: Temu IPLBI. doi: https://doi.org/10.32315/ti.6.a001

Sarwono, WS. (1992). Psikologi Lingkungan. Jakarta: Gramedia

Undang Undang RI No 26 tahun 2007 tentang Tata Ruang

Sumber gambar sesuai urutan:

90 Tempat Wisata di semarang Paling Menarik dan Wajib Dikunjungi. Diakses pada Januari 2021, dari https://www.tempatwisata.pro/wisata/ Semarang

Mengapa Warak Ngendog Menjadi Ikon Kota Semarang. Diakses pada Januari 2021, dari

https://energibangsa.id/mengapawarak-ngendog-jadi-icon-kotasemarang/

Taman Tirto Agung Banyumanik, Alternatif Refrshing Keluarga. Diakses pada Januari 2021, dari http://www.kontenpedia.com/detail/ne ws/482094/gaya\%20hidup/tamantirto-agung-banyumanik-alternatifrefresing-keluarga-

Bersantai Sambil Kulineran atau Berolahraga? Taman Tirto Agung Semarang Bisa Jadi Jujugan. Diakses pada Januari 2021, dari https://jateng.tribunnews.com/2017/01 /25/bersantai-sambil-kulineran-atauberolahraga-taman-tirto-agungsemarang-bisa-jadi-jujugan
Bendungan Sungai Banjirkanal Barat. Diakses pada Januari 2021, dari https://pemkotsemarang2016.wordpres s.com/2017/03/05/bendungan-sungaibanjir-kanal-barat/

Senam di Taman Bantaran Sungai BKB Semarang. Diakses pada Januari 2021, dari https://lihatfoto.com/senam-ditaman-bantaran-sungai-bkb-semarang$\underline{17030}$

Enam Spot Foto Paling Ngehit di Taman Srigunting Semarang. Nyesel Kalau Ngga Narsis di Sini!. Diakses pada Januari 2021, dari https://jateng.tribunnews.com/2017/11 /01/enam-spot-foto-paling-ngehit-ditaman-srigunting-semarang-nyeselkalau-ngga-narsis-di-sini

Photo: Taman Srigunting, Semarang, Kota Lama. Diakses pada Januari 2021, dari https://www.tripadvisor.com/Location PhotoDirectLink-g297712d10162130-i304564631-

Taman_Srigunting-

Semarang_Central_Java_Java.html

10 Foto Indahnya Taman Indonesia Kaya Semarang. Diakses Januari 2021, dari https://jejakpiknik.com/tamanindonesia-kaya/

Dari Panggung Budaya Sampai Seni Instalasi Tokoh Pewayangan. Diakses pada Januari 2021, dari https://www.brilio.net/wow/7-spotkece-taman-indonesia-kaya-adagerbang-mural-yang-instagramable$\underline{\text { 1810137.html\# }}$ 